\title{
Organic acids and hydrogen peroxide can replace chlorinated compounds as sanitizers on strawberries, cucumbers and rocket leaves
}

\author{
Bárbara Morandi LEPAUS ${ }^{1}$, Jéssica Souza ROCHA², Jackline Freitas Brilhante de SÃO JOSÉ1,3* (D)
}

\begin{abstract}
This work evaluated the effectiveness of 1 and 2\% acetic and lactic acid, 3\% hydrogen peroxide, $200 \mathrm{mg} / \mathrm{L}$ sodium hypochlorite and $200 \mathrm{mg} / \mathrm{L}$ sodium dichloroisocyanurate to reducing natural contaminants as well as Salmonella enterica Enteritidis inoculated on the surface of strawberries, cucumbers, and rocket leaves. The reduction of aerobic mesophilic and molds and yeasts was between $1.67-2.73$ and $0.61-1.46 \log$ CFU/g in strawberries, $1.48-2.19$ and $1.02-2.01 \mathrm{log}$ CFU/g on rocket leaves, and $1.10-2.08$ and $0.88-1.58 \log$ CFU/g in cucumbers, respectively. The most effective sanitizers for reducing Salmonella enterica Enteritidis in strawberries were $1 \%$ and $2 \%$ lactic acid, while in cucumbers and rocket leaves was the $2 \%$ lactic acid as well as the $3 \%$ hydrogen peroxide, for both samples. The results of this study clearly show the potential of the proposed strategies to replace chlorinated compounds in the sanitization step of fresh produce.
\end{abstract}

Keywords: ready-to-eat food; non-chlorinated sanitizers; microbial load; food safety; quality.

Practical Application: Investigate alternatives in the sanitization step of fruits and vegetables.

\section{Introduction}

The industry of minimally processed fruits and vegetables, as well as the consumption of these foods, has grown significantly in recent years (Joshi et al., 2013; Rosário et al., 2017). Minimally processed foods, or ready-to-eat (RTE), are those that have undergone selection, washing, sanitizing, peeling and/or cutting, and subsequent appropriate packaging during processing, in order to obtain products ready for immediate consumption (Paula et al., 2009; Smanioto et al., 2009). However, the increase in the market and consumption of RTE has been correlated with an increase in the incidence of foodborne disease outbreaks due to the ingestion of fruits and vegetables contaminated by pathogens.

Among the microorganisms most involved in the occurrence of foodborne outbreaks involving fresh products are Salmonella spp., Escherichia coli, Listeria monocytogenes, and Shigella spp. Salmonella is a major foodborne bacterium that causes gastroenteritis and is estimated to be responsible for approximately 3 million cases of foodborne illness in China and 1 million cases in the United States of America (Guo et al., 2016). From 2013 to 2016, several Salmonella outbreaks have been reported worldwide, with one outbreak per year attributed to the consumption of cucumbers contaminated with this pathogen in the USA (Angelo et al., 2015; Bottichio et al., 2016; Centers for Disease Control and prevention, 2016). In Brazil, from 2000 to 2015, 11,241 outbreaks of foodborne illness were registered (Food Safety Brazil, 2016). According to the Epidemiological Surveillance of Foodborne Diseases in Brazil, the cases of outbreak increased by $10 \%$ from 2016 to 2017 . Salmonella spp. accounted for the largest number of cases (35\%) whose cause was identified (Food Safety Brazil, 2019).
The increase of new cases due to the inefficiency in the production and processing stages, as during sanitization, can result in complications in several countries (Fernandes et al., 2014). The efficiency of washing and sanitizing processes is directly related to the microbiological quality of the final product (Ramos et al., 2013; Rosário et al., 2017). Washing with potable water allows the removal of soil components and some of the pathogens but alone is not sufficient to significantly reduce the microbial load present in the food (Joshi et al., 2013; Gomes et al., 2014). The sanitization step is a key point for the microbiological control of foods (Joshi et al., 2013; São José et al., 2014) in order to ensure microbial control and food safety.

Usually, it is common to use chlorine-based compounds, especially sodium hypochlorite, during the sanitization of vegetables. These compounds are recommended in Brazil (Brasil, 1988; Brasil, 2007), but several European countries such as Germany, Belgium, Holland, and Sweden have prohibited the use of these compounds in the sanitization of fruits and vegetables (Rico et al., 2007). A concern about use of chlorine compounds is their potential for negative interactions with organic load contributed by plant tissue or other contaminants encountered during pre-harvest to post-harvest handling. The discussion on the use of chlorinated compounds is related to the possibility of generating highly carcinogenic by-products, which is of environmental problem (São José \& Vanetti, 2012). In addition, the washing and use of chlorinated compounds may not be fully effective in the disinfection step of RTE (Huang et al., 2012; Rosário et al., 2017) because of the limited reduction of the contamination by 1 to $2 \log \mathrm{CFU} / \mathrm{g}$. Therefore, studies on 
new disinfection strategies can contribute to the microbiological safety of the food (Huang \& Chen, 2011; Sagong et al., 2011; Joshi et al., 2013; São José \& Vanetti, 2015; Rosário et al., 2017; São José et al., 2018).

Lactic, acetic and citric acids are examples of organic acids that can be applied in the sanitization process. These substances are considered as generally recognized as safe (GRAS) and are acknowledged for their ability to act on a broad spectrum of bacteria with rapid inhibition of microbial cells present in food (Akbas \& Ölmez, 2007; Huang \& Chen, 2011; In et al., 2013; Sagong et al., 2011). Another alternative sanitizer is hydrogen peroxide due to its high oxidation power and highly bacteriostatic and bactericidal properties, including bacterial spore reduction. In addition, it does not react with organic components and does not form toxic waste. For these reasons, it has been gaining prominence in the minimum processing industry (Ölmez \& Kretzschmar, 2009). These sanitizers can be used in the processing of RTE and can thus assist processers in adapting to new market trends. This work aimed to evaluate the application of organic acids and hydrogen peroxide in removing the natural contaminants microbiota and Salmonella enterica Enteritidis intentionally inoculated on the surface of strawberries, cucumbers, and rocket leaves.

\section{Materials and methods}

\subsection{Obtaining the samples and sanitizers treatments}

Samples of strawberries (Fragaria $x$ ananassa Duch), cucumbers (Cucumis sativus L. var Aodai) and rocket leaves (Eruca sativa L.) were acquired from the local market of Vitória (Espírito Santo State, Brazil) and stored at $7{ }^{\circ} \mathrm{C}$ for a maximum of $24 \mathrm{~h}$ before processing. Before the analyses, the vegetables were selected and damaged or rotten ones were discarded. The stems were removed from yellowing rocket leaves. They were then washed in water to remove dirt that had adhered to the surface and were then drained for 10 minutes. The sanitization step consisted of the isolated immersion of approximately $200 \mathrm{~g}$ of strawberries, a unit of cucumber (approximately $250 \mathrm{~g}$ ) and $50 \mathrm{~g}$ of rocket leaves in $1 \mathrm{~L}$ of sanitizing solution to analyze the efficiency against natural microbial contamination. In the analysis of Salmonella Enteritidis cell contamination, immersion occurred with approximately $100 \mathrm{~g}$ of strawberries, a unit of cucumber (approximately $250 \mathrm{~g}$ ) and $25 \mathrm{~g}$ of rocket leaves in $500 \mathrm{~mL}$ of solution.

Sanitizing solutions were prepared immediately prior to use, and immersion occurred for $5 \mathrm{~min}$ at $20 \pm 1^{\circ} \mathrm{C}$. The concentrations and time of exposure were based on previous experiments and scientific literature. The effects of the following sanitizing agents were evaluated: $1 \%$ and $2 \%$ lactic acid (Neon ${ }^{\circledR}$, Suzano, São Paulo, Brazil), $1 \%$ and $2 \%$ acetic acid (Fmaia ${ }^{\circledR}$, Belo Horizonte, Minas Gerais, Brazil) and 3\% hydrogen peroxide (Scientific Exodus ${ }^{\circledR}$, Hortolândia, São Paulo, Brazil). Sanitization treatments with chlorinated compounds ( $200 \mathrm{mg} / \mathrm{L}$ sodium dichloroisocyanurate (Nippoclor $^{\circledR}$, Indaiatuba, São Paulo, Brazil) and $200 \mathrm{mg} / \mathrm{L}$ sodium hypochlorite (Hidrosteril ${ }^{\circledR}$, Itapevi, São Paulo, Brazil)) were carried out to compare the efficiency of the proposed sanitizers.
The control was the sample only washed in running water and did not undergo the sanitation stage.

The $\mathrm{pH}$ value of each sanitizer was measured in $50 \mathrm{~mL}$ of each prepared solution using a digital potentiometer (Tecnopon ${ }^{\circledR}$, mPA210, Piracicaba, São Paulo, Brazil).

\subsection{Evaluation of sanitation procedures to removal natural microbial contamination}

This step was carried out in accordance with the American Public Health Association (APHA), as described in the Compendium of Methods for the Microbiological Examination of Foods (Downes \& Ito, 2001).

After each treatment, $25 \mathrm{~g}$ of each sample were rinsed and homogenized in $225 \mathrm{~mL}$ of $0.1 \%$ peptone water using a stomacher (Seward Medical Co., London, United Kingdom). Appropriate serial dilutions were prepared for inoculation in standard plate count agar (PCA) (Difco ${ }^{\circledR}$ ) that was incubated for $48 \mathrm{~h}$ at $35 \pm 1^{\circ} \mathrm{C}$ to determine the number of aerobic mesophilic bacteria. Mold and yeast aliquots were inoculated on potato dextrose agar (PDA) $\left(\mathrm{Oxoid}^{\circledR}\right)$ at a $\mathrm{pH}$ of 3.5 and incubated at $25 \pm 2{ }^{\circ} \mathrm{C}$ for 5 to 7 days. For both analyses, plots of the two dilutions were made in duplicate. The result was expressed in $\log$ of colony forming units per gram (log CFU/g).

\subsection{Challenge test to evaluate the efficiency of sanitizers in the removal of Salmonella enterica Enteritidis ATCC 13076}

This test evaluated the potential of the different sanitizers for the inactivation of Salmonella enterica Enteritidis (ATCC 13076) intentionally inoculated on the samples. Vegetables were selected, cleaned and rinsed with sterile distilled water. A suspension of Salmonella enterica serovar Enteritidis (ATCC 13076) vegetative cells was utilized. From a pure culture of bacteria maintained at $-80{ }^{\circ} \mathrm{C}$ in Eppendorf ${ }^{\circledR}$ tubes containing Brain Heart Infusion (BHI) and glycerol (80:20, v:v), we prepared suspensions containing approximately $1.0 \times 10^{7} \mathrm{CFU} / \mathrm{mL}$ of bacteria. For use in trials, suspensions of vegetative cells were produced in two consecutive subcultures in $\mathrm{BHI}$ broth by incubation at $35^{\circ} \mathrm{C}$ for $24 \mathrm{~h}$. The culture was preserved in $1 \mathrm{~mL}$ microtubes containing BHI (Himedia ${ }^{\circledR}$ ), activated by two consecutive BHI replications, and incubated at $37{ }^{\circ} \mathrm{C}$ for $24 \mathrm{~h}$ until reaching a population of $10^{6}$ to $10^{7} \mathrm{CFU} / \mathrm{mL}$. The number of microorganisms in the suspensions was determined by plating on Salmonella-Shigella agar (Himedia ${ }^{\circledR}$, Brazil) and incubating the plates at $35^{\circ} \mathrm{C}$ for $24 \mathrm{~h}$.

Inoculation procedures were conducted according to São José (2013) with approximately $100 \mathrm{~g}$ of strawberries, $250 \mathrm{~g}$ of cucumbers and $25 \mathrm{~g}$ of rocket leaves that were placed separately in a previously sterilized plastic bags. The inoculum $(10 \mathrm{~mL})$ was added along with $500 \mathrm{~mL}$ of $0.1 \%$ peptone water. The bag containing the inoculum and the vegetable was gently shaken for 5 minutes. The samples were kept in contact with the cell suspension for 60 minutes at $25 \pm 1^{\circ} \mathrm{C}$. The cell suspension was drained, and the strawberries and cucumbers contaminated with Salmonella were placed in sterile plastic bags and incubated at $25^{\circ} \mathrm{C}$ for $24 \mathrm{~h}$ to allow for better adherence of the bacteria. Nevertheless, the rocket leaves were kept at the same temperature 
for 1 hour, due to the characteristic of the sample. Afterward, contaminated samples were immersed in $500 \mathrm{~mL}$ of sanitizing solution for 5 minutes at $7 \pm 1^{\circ} \mathrm{C}$.

After each treatment, $10 \mathrm{~g}$ samples of each vegetable were transferred to sterilized plastic bags containing $90 \mathrm{~mL}$ of $0.1 \%$ peptone water and were then homogenized in a stomacher (Marconi ${ }^{\circledR}$, MA440/CF, Piracicaba, São Paulo, Brazil) for 2 min at normal speed. Then, $1 \mathrm{~mL}$ of the sample was used to prepare decimal dilutions plated on the surface of Salmonella-Shigella agar (Himedia ${ }^{\circledR}$, Brazil). After incubation for 18 to $24 \mathrm{~h}$ at $37^{\circ} \mathrm{C}$, the colonies were counted, and the results were expressed as $\log \mathrm{CFU} / \mathrm{g}$.

\subsection{Statistical analyses}

Three experimental repetitions were conducted for each sanitizing treatment. The results were analyzed with the InfoStat Statistical Software (version 2012, Cordoba National University, Argentina). The analysis of variance (ANOVA) was applied. The average logarithms of the number of colonies forming units per gram $(\log 10 \mathrm{CFU} / \mathrm{g})$ for each treatment were compared using Tukey's test at a $5 \%$ probability.

\section{Results and discussion}

\subsection{Ph evaluation of sanitizing solutions}

The $2 \%$ acetic acid solution had the lowest $\mathrm{pH}$ value among the sanitizers evaluated (Table 1). $\mathrm{pH}$ control in the sanitization solution is fundamental to the efficiency of the operation because can contributed to bactericidal effect.

Table 1. Values of $\mathrm{pH}$ averages of sanitization treatments at a temperature of $24 \pm 1^{\circ} \mathrm{C}$.

\begin{tabular}{lc}
\hline \multicolumn{1}{c}{ Treatments } & $\mathrm{pH}$ \\
\hline 1\% Lactic Acid & $2.51^{\mathrm{d}} \pm 0.05$ \\
2\% Lactic Acid & $2.33^{\mathrm{d}} \pm 0.06$ \\
1\% Acetic Acid & $1.89^{\mathrm{e}} \pm 0.04$ \\
2\% Acetic Acid & $1.72^{\mathrm{f}} \pm 0.05$ \\
3\% Hydrogen Peroxide & $3.98^{\mathrm{b}} \pm 0.16$ \\
200 mg/L Sodium Dichloroisocyanurate & $6.55^{\mathrm{a}} \pm 0.06$ \\
200mg/L Sodium Hypochlorite & $6.50^{\mathrm{a}} \pm 0.22$ \\
\hline
\end{tabular}

Different letters in the same column indicate statistically significantly different at $\mathrm{p} \leq 0.05$ by Tukey Test.

\subsection{Evaluation of the efficiency of sanitizers to removal natural microbial contamination}

\section{Strawberries}

All evaluated treatments significantly reduced the initial strawberry contamination $(\mathrm{p} \leq 0.05)$. The reduction of aerobic mesophilic bacteria contamination ranged from 1.67 to $2.73 \log \mathrm{CFU} / \mathrm{g}$. There was no significant difference $(p>0.05)$ between the proposed treatments and the chlorinated compounds (Table 2). The results indicate that the treatments with organic acids and hydrogen peroxide were compatible with treatments with chlorinated compounds and could be an alternative. The reduction values for aerobic mesophilic bacteria by acetic acid at $1 \%$ and $2 \%$ were equal to 2.59 and $2.73 \log \mathrm{CFU} / \mathrm{g}$, respectively.

Nascimento \& Silva (2010) found that $2 \%$ acetic acid reduced $1.90 \log$ CFU/g for aerobic mesophilic bacteria in strawberries. However, sodium dichloroisocyanurate and sodium hypochlorite, sanitizers based on chlorine, reduced 1.55 and $1.25 \log \mathrm{CFU} / \mathrm{g}$, respectively. Moreover, the authors verified that $4 \%$ acetic acid sanitization reduced $2.43 \log \mathrm{CFU} / \mathrm{g}$, which indicates that despite the use of a higher concentration of active ingredient there was no further reduction in the count of aerobic mesophilic bacteria. This result may occur due to factors that indirectly interfere with the effectiveness of sanitizers, such as the anatomy, contact area, and structure of plant tissues (São José \& Vanetti, 2015).

The treatment with hydrogen peroxide reduced $1.85 \log \mathrm{CFU} / \mathrm{g}$, and the result is similar to that found by Alexandre et al. (2012), who sanitized strawberry samples with the same sanitizer at a concentration of $1 \%$ and $5 \%$ for 2 minutes and obtained a reduction of $1.46 \log \mathrm{CFU} / \mathrm{g}$ and $2.25 \mathrm{log} \mathrm{CFU} / \mathrm{g}$, respectively. The efficiency of sanitization involves other factors in addition to concentration and time of exposition, such as the surface characteristics of the food, formation of resistant biofilms, temperature, and pH (São José et al., 2014).

Treatments with $1 \%$ and $2 \%$ lactic acid, $2 \%$ acetic acid and with hydrogen peroxide promoted a reduction of aerobic mesophilic bacteria as well as the molds and yeasts statistically equal to chlorinated compounds ( $p>0.05$ ). In this study, both concentrations of organic acids applied were able to reduce the natural contamination of aerobic mesophilic bacteria and yeasts and molds in a similar proportion, which suggests the possibility of using the lowest concentration. Some factors

Table 2. Averages (log CFU/g) of the counts of the contaminating natural microbiota and Salmonella Enteritidis cells adhered to strawberries without sanitizing and submitted to different sanitization treatments for 5 minutes.

\begin{tabular}{lccc}
\hline \multirow{2}{*}{ Treatments } & \multicolumn{3}{c}{ Log CFU/g \pm Standard Deviation } \\
\cline { 2 - 4 } & Aerobic mesophiles & Molds and Yeats & Salmonella Enteritidis \\
\hline No Sanitizer & $5.88^{\mathrm{a}} \pm 0.20$ & $6.04^{\mathrm{a}} \pm 0.23$ & $5.13^{\mathrm{a}} \pm 0.41$ \\
$1 \%$ Lactic Acid & $3.87^{\mathrm{b}} \pm 1.41$ & $4.73^{\mathrm{c}} \pm 0.32$ & $3.22^{\mathrm{c}} \pm 0.39$ \\
2\% Lactic Acid & $3.57^{\mathrm{b}} \pm 1.18$ & $4.64^{\mathrm{c}} \pm 0.18$ & $3.05^{\mathrm{c}} \pm 0.04$ \\
$1 \%$ Acetic Acid & $3.29^{\mathrm{b}} \pm 1.07$ & $5.43^{\mathrm{b}} \pm 0.38$ & $4.38^{\mathrm{b}} \pm 0.11$ \\
2\% Acetic Acid & $3.15^{\mathrm{b}} \pm 0.85$ & $4.58^{\mathrm{c}} \pm 0.40$ & $4.24^{\mathrm{b}} \pm 0.10$ \\
3\% Hydrogen Peroxide & $4.03^{\mathrm{b}} \pm 0.76$ & $4.74^{\mathrm{c}} \pm 0.23$ & $4.38^{\mathrm{b}} \pm 0.10$ \\
200 mg/L Sodium Dichloroisocyanurate & $4.21^{\mathrm{b}} \pm 0.76$ & $4.64^{\mathrm{c}} \pm 0.37$ & $4.23^{\mathrm{b}} \pm 0.14$ \\
200mg/L Sodium Hypochlorite & $4.01^{\mathrm{b}} \pm 0.71$ & $4.65^{\mathrm{c}} \pm 0.50$ & $4.59^{\mathrm{b}} \pm 0.12$ \\
\hline
\end{tabular}

Different letters in the same column indicate statistically significantly different at $\mathrm{p} \leq 0.05$ by Tukey Test. 
should be evaluated when considering a sanitizer as ideal, such as being able to destroy microorganisms quickly and having a broad spectrum of antimicrobial action, in addition to presenting low toxicity and corrosivity and being stable under several conditions of use (Andrade et al., 2008). Nascimento \& Silva (2010) subjected strawberries to sanitizing procedures with $2 \%$ and $4 \%$ of acetic acid, and $50 \%$ vinegar solutions and obtained results that demonstrated that the use of this sanitizer was effective under various conditions of use, thus fulfilling one of the aforementioned criteria.

\section{Cucumbers}

All treatments significantly reduced the initial contamination $(\mathrm{p} \leq 0.05)$. However, there was no significant difference $(\mathrm{p}>0.05)$ for the contaminating natural microbiota among the evaluated treatments. The reduction of aerobic mesophilic bacteria contamination ranged from 1.10 to $2.08 \log$ CFU/g (Table 3).

As with the strawberry samples, the reductions of molds and yeasts by $1 \%$ and $2 \%$ acetic acid had similar values, $1.32 \log \mathrm{CFU} / \mathrm{g}$, and $1.33 \log \mathrm{CFU} / \mathrm{g}$, respectively, which demonstrates that the lowest concentration is feasible. Ukuku (2006) obtained better results in the sanitation of melons using $2.5 \%$ hydrogen peroxide and $200 \mathrm{mg} / \mathrm{L}$ sodium hypochlorite. The difficulty in promoting the reduction of microorganisms of some foods can be explained by the characteristic repellency of their surface due to the presence of hydrophobic multilayers (São José et al., 2014).

\subsubsection{Rocket leaves}

All treatments were able to significantly reduce the initial contamination $(\mathrm{p} \leq 0.05)$ (Table 4$)$. The reduction of aerobic mesophilic bacteria contamination in rocket leaves ranged from 1.27 to $2.19 \log \mathrm{CFU} / \mathrm{g}$. In addition, for aerobic mesophilic bacteria, all alternative treatments proposed were statistically the same as the chlorinated compounds ( $p>0.05$ ). The present study showed that both concentrations of acetic acid tested were effective in removing aerobic mesophiles. High initial counts of microorganisms may be related to the way the plants are produced; for example, in the case of leaves, growing near the soil makes them prone to contamination. The presence of microorganisms on the leaves at the time of harvesting is one of the main challenges in the post-harvest handling of fresh products because that can initiate the process of deterioration during storage (Wieczyńska et al., 2016).

Zhang \& Yang (2017), when evaluating potential sanitizers in organic and conventional lettuce, found that aerobic mesophilic populations in samples treated with $0.6 \%$ citric acid and $1 \%$ hydrogen peroxide had counts equal to 5.58 and $4.61 \mathrm{log} \mathrm{CFU} / \mathrm{g}$, respectively, while the population of molds and yeast were 4.74 and $3.78 \log \mathrm{CFU} / \mathrm{g}$, respectively. Fantuzzi et al. (2004) found no significant difference in the reduction of the contaminant microbiota in cabbage samples treated with $1 \%$ acetic acid when compared to the microbiota reduction with the water wash process only.

Table 3. Averages (log CFU/g) of the counts of the contaminating natural microbiota and Salmonella Enteritidis cells adhered to cucumbers without sanitizing and submitted to different sanitization treatments for 5 minutes.

\begin{tabular}{lccc}
\hline \multicolumn{1}{c}{ Treatments } & & Log CFU/g \pm Standard Deviation \\
\cline { 2 - 4 } & Aerobic mesophiles & Molds and Yeats & Salmonella Enteritidis \\
\hline No Sanitizer & $6.19^{\mathrm{a}} \pm 0.16$ & $6.54^{\mathrm{a}} \pm 0.20$ & $5.07^{\mathrm{a}} \pm 0.04$ \\
$1 \%$ Lactic Acid & $4.47^{\mathrm{b}} \pm 0.73$ & $4.96^{\mathrm{b}} \pm 1.06$ & $3.66^{\mathrm{b}} \pm 0.14$ \\
2\% Lactic Acid & $4.11^{\mathrm{b}} \pm 0.81$ & $5.09^{\mathrm{b}} \pm 0.53$ & $2.72^{\mathrm{de}} \pm 0.36$ \\
$1 \%$ Acetic Acid & $4.45^{\mathrm{b}} \pm 1.11$ & $5.22^{\mathrm{b}} \pm 0.12$ & $3.69^{\mathrm{b}} \pm 0.31$ \\
2\% Acetic Acid & $4.35^{\mathrm{b}} \pm 0.38$ & $5.21^{\mathrm{b}} \pm 0.15$ & $2.99^{\mathrm{cd}} \pm 0.24$ \\
3\% Hydrogen Peroxide & $5.09^{\mathrm{b}} \pm 0.29$ & $5.13^{\mathrm{b}} \pm 0.15$ & $2.36^{\mathrm{e}} \pm 0.22$ \\
200 mg/L Sodium Dichloroisocyanurate & $4.81^{\mathrm{b}} \pm 0.69$ & $5.66^{\mathrm{b}} \pm 0.49$ & $3.47^{\mathrm{bc}} \pm 0.51$ \\
200mg/L Sodium Hypochlorite & $5.13^{\mathrm{b}} \pm 0.35$ & $5.51^{\mathrm{b}} \pm 0.48$ & $3.45^{\mathrm{bc}} \pm 0.16$ \\
\hline
\end{tabular}

Different letters in the same column indicate statistically significantly different at $\mathrm{p} \leq 0.05$ by Tukey Test.

Table 4. Averages (log CFU / g) of the counts of the contaminating natural microbiota and Salmonella Enteritidis cells adhered to rocket leaves without sanitizing and submitted to different sanitization treatments for 5 minutes.

\begin{tabular}{lccc}
\hline \multicolumn{1}{c}{ Treatments } & \multicolumn{3}{c}{ Log CFU/g \pm Standard Deviation } \\
\cline { 2 - 4 } & Aerobic mesophiles & Molds and Yeats & Salmonella Enteritidis \\
\hline No Sanitizer & $7.01^{\mathrm{a}} \pm 0.35$ & $6.43^{\mathrm{a}} \pm 0.06$ & $5.26^{\mathrm{a}} \pm 0.09$ \\
$1 \%$ Lactic Acid & $5.74^{\mathrm{b}} \pm 0.47$ & $5.43^{\mathrm{b}} \pm 0.17$ & $3.55^{\mathrm{d}} \pm 0.12$ \\
2\% Lactic Acid & $4.97^{\mathrm{b}} \pm 0.50$ & $4.42^{\mathrm{c}} \pm 0.22$ & $2.15^{\mathrm{e}} \pm 0.21$ \\
$1 \%$ Acetic Acid & $5.53^{\mathrm{b}} \pm 0.89$ & $5.41^{\mathrm{b}} \pm 0.11$ & $4.04^{\mathrm{c}} \pm 0.04$ \\
2\% Acetic Acid & $5.21^{\mathrm{b}} \pm 1.09$ & $4.63^{\mathrm{c}} \pm 0.62$ & $3.37^{\mathrm{d}} \pm 0.12$ \\
3\% Hydrogen Peroxide & $4.82^{\mathrm{b}} \pm 0.36$ & $4.53^{\mathrm{c}} \pm 0.02$ & $2.36^{\mathrm{e}} \pm 0.26$ \\
200 mg/L Sodium Dichloroisocyanurate & $5.03^{\mathrm{b}} \pm 0.97$ & $5.44^{\mathrm{b}} \pm 0.40$ & $3.22^{\mathrm{d}} \pm 0.11$ \\
200mg/L Sodium Hypochlorite & $5.36^{\mathrm{b}} \pm 0.84$ & $5.29^{\mathrm{b}} \pm 0.52$ & $4.50^{\mathrm{b}} \pm 0.02$ \\
\hline
\end{tabular}

Different letters in the same column indicate statistically significantly different at $\mathrm{p} \leq 0.05$ by Tukey Test. 
However, it is worth mentioning that each plant has different roughness and hydrophobicity, which may influence the sanitizing antimicrobial efficiency (Data not shown). The increase in the mean roughness value of the surfaces may favor higher retention of microorganisms on the surface (Lima et al., 2013).

According to Yuk et al. (2006), the microstructures of plant tissues, grooves, cracks, cavities and other irregularities of the vegetable surface can affect the contact of the sanitizing solution with the target microorganisms and, consequently, the efficiency of the process.

When evaluating the use of sanitizers in the present study against molds and yeasts, it was verified that $2 \%$ acetic acid, $2 \%$ lactic acid and hydrogen peroxide were statistically better than the other treatments, reducing 1.80, 2.01 and $1.90 \log \mathrm{CFU} / \mathrm{g}$, respectively. It is noteworthy that sodium dichloroisocyanurate obtained a smaller reduction than these procedures, reducing less than $1 \log \mathrm{CFU} / \mathrm{g}$.

\section{Evaluation of the efficiency of sanitizers in Salmonella enterica Enteritidis cells ATCC 13076}

The sanitization treatments that showed the greatest effect on the reduction of Salmonella Enteritidis cells in strawberries were $1 \%$ and $2 \%$ lactic acid, with a reduction of $1.91 \mathrm{log} \mathrm{CFU} / \mathrm{g}$ and $2.08 \log \mathrm{CFU} / \mathrm{g}$, respectively (Table 2). These results are similar to the findings of Park et al. (2011), in which $1 \%$ lactic acid reduced $1.78 \mathrm{log} \mathrm{CFU} / \mathrm{g}$ and $2 \%$ lactic acid reduced $2.53 \log$ CFU/g in apple samples contaminated with Salmonella Typhimurium. Fernandes (2013) confirmed that solutions of $1 \%$ and $2 \%$ lactic acid promoted a higher reduction, compared to other treatments in strawberries contaminated with $E$. coli cells. Gurtler et al.(2014) evaluated different sanitizers for 2 minutes to remove four serovars of Salmonella enterica from strawberries and found higher reductions from treatment with 3\% hydrogen peroxide compared to lactic and acetic acids, both $1 \%$.

The cucumber samples had initial contamination of Salmonella Enteritidis cells of $5.07 \pm 0.04 \mathrm{log}$ CFU/g and after the treatments with hydrogen peroxide and $2 \%$ lactic acid reductions of $2.71 \log \mathrm{CFU} / \mathrm{g}$ and $2.34 \log \mathrm{CFU} / \mathrm{g}$, respectively, were achieved (Table 3). Different from the results of natural microbial counts after sanitization treatments, the reduction of the pathogen in the cucumber samples was higher when the concentration of organic acids increased. Guo et al. (2016) evaluated the action of hydrogen peroxide at 2.5 and $5 \%$ for one minute on slices of cucumber intentionally contaminated with Salmonella Choleraesuis and observed a reduction of 0.9 and $1.6 \log \mathrm{CFU} / \mathrm{g}$, respectively. Amrutha et al. (2017) obtained a lower reduction (0.17 log CFU/g) of Salmonella spp. when compared to the present study after sanitizing cucumber with $2 \%$ lactic acid. Ukuku (2004) investigated the action of the hydrogen peroxide at $2.5 \%$ and $5 \%$ in the reduction of Salmonella spp. cells on the surface of cantaloupe and honeydew melons. In the first melon variety, the lowest concentration promoted a reduction of $2.56 \log \mathrm{CFU} / \mathrm{g}$. However, an increase in concentration did not enhance the reduction. In honeydew melons, both hydrogen peroxide concentrations reduced $3.00 \mathrm{log} \mathrm{CFU} / \mathrm{g}$ from initial contamination. The increase of the concentration of hydrogen peroxide $(0.5,1$, and $2 \%)$ also did not cause statistical differences in the counts of E. coli ATCC 25922 and Salmonella Enteritidis after sanitization of fresh-cut snap bean (Palharini et al., 2017). In a study on the sanitization of melons and green peppers contaminated with Salmonella Enteritidis, São José et al. (2014) applied the same sanitizer at $1 \%$ concentration and obtained reduction of $1.80 \log \mathrm{CFU} / \mathrm{g}$ and $2.00 \mathrm{log} \mathrm{CFU} / \mathrm{g}$, respectively.

The reductions in rocket leaves varied from 0.76 to $3.11 \log \mathrm{CFU} / \mathrm{g}$. All evaluated treatments significantly decreased the counts of S. enterica Enteritidis ( $\mathrm{p} \leq 0.05)$. The highest reductions were from sanitization with $2 \%$ lactic acid and hydrogen peroxide, which reduced the counts by 3.11 and $2.90 \log \mathrm{CFU} / \mathrm{g}$, respectively (Table 4). Similar to the cucumber results, the increase of the organic acids concentration enhanced the reduction of Salmonella Enteritidis cells in the rocket leaves. Lactic acid is an organic acid considered as GRAS and can be used for the removal of surface contamination or as a preservative and flavoring agent in foods (Poimenidou et al., 2016). Neal et al. (2012) obtained a reduction of $2.3 \mathrm{log} \mathrm{CFU} / \mathrm{g}$ of Salmonella spp. when using lactic acid at $2 \%$ in spinach leaves. Zhang et al. (2015) used 3\% hydrogen peroxide and found a smaller reduction to that found in this study, $1.5 \log$ CFU/g of Salmonella Typhimurium cells in spinach leaves. Poimenidou et al. (2016) found that the addition of $300 \mathrm{mg} / \mathrm{L}$ of active chlorine in the treatment solution promoted a reduction of $1.7 \log \mathrm{CFU} / \mathrm{g}$ of $E$. coli $\mathrm{O} 157: \mathrm{H} 7 \mathrm{in}$ spinach leaves. Valiolahi et al. (2019) tested different treatments with $2 \%$ of organic acids (acetic, lactic, and citric), and found that basil leaves samples treated with acetic acid presented the highest inhibition effects of Escherichia coli O157:H7 growth at the first day of storage. An antimicrobial formulation (3\% hydrogen peroxide, $0.02 \mathrm{mM}$ ethylenediaminetetraacetic acid (EDTA), and $20 \mathrm{mg} / \mathrm{ml} \mathrm{Nisin)}$ tested by Mukhopadhyay et al. (2019) reduced $1.8 \mathrm{log}$ CFU/g the count of E. coli O157:H7 of spinach leaves.

The microbial inactivation of organic acids can occur due to the damage and break in the function of the cell wall. The undissociated form of organic acid diffuses through freely the microbial membrane and inhibits enzymatic reactions as well as modifies proteins and DNA structure (Mani-López et al., 2012; Wang et al., 2015). The efficiency of hydrogen peroxide is related to damages caused in DNA of the microorganisms due to its high oxidation power (Linley et al., 2012).

\section{Conclusion}

Based on their antimicrobial action, the proposed sanitizers were as efficient as the chlorinated compounds in reducing the contamination of aerobic mesophilic bacteria in strawberries, cucumbers and rocket leaves. In the cucumber samples, there was a higher reduction in the contamination of molds and yeasts when $1 \%$ and $2 \%$ lactic acid was applied. The treatments that demonstrated the greatest effect on the reduction of Salmonella enterica Enteritidis cells in intentionally contaminated strawberries were $1 \%$ and $2 \%$ lactic acid. However, in the cucumber and rocket samples, $2 \%$ lactic acid and 3\% hydrogen peroxide treatments promoted a greater reduction of the pathogen. All the evaluated treatments had a similar or better performance than the chlorinated compounds; therefore, they have a potential for use as alternatives in the sanitization of fresh fruits and 
vegetables. Nevertheless, complementary studies are needed to evaluate the impact of these sanitizers on sensory qualities and economic viability.

\section{Acknowledgements}

The authors gratefully acknowledge the Foundation for the Support of Research and Innovation of Espírito Santo (FAPES) for financial support for project on number 554/2015 approved on Edital Fapes no. 006/2014. We thank Conselho Nacional de Desenvolvimento Científico e Tecnológico (CNPq/Brasil) for the scholarship of one of the authors. We thank Fundo de Apoio à Pesquisa of Universidade Federal do Espírito Santo (FAP/UFES) for all support.

\section{References}

Akbas, M. Y., \& Ölmez, H. (2007). Inactivation of Escherichia coli and Listeria monocytogenes on iceberg lettuce by dip wash treatments with organic acids. Letters in Applied Microbiology, 44(6), 619-624. http://dx.doi.org/10.1111/j.1472-765X.2007.02127.x. PMid:17576223.

Alexandre, E. M. C., Brandão, T. R. S., \& Silva, C. L. M. (2012). Assessment of the impact of hydrogen peroxide solutions on microbial loads and quality factors of red bell peppers, strawberries and watercress. Food Control, 27(2), 362-368. http://dx.doi.org/10.1016/j. foodcont.2012.04.012.

Amrutha, B., Sundar, K., \& Shetty, P. H. (2017). Effect of organic acids on biofilm formation and quorum signaling of pathogens from fresh fruits and vegetables. Microbial Pathogenesis, 111, 156-162. http://dx.doi.org/10.1016/j.micpath.2017.08.042. PMid:28867627.

Andrade, N. J., Pinto, C. L. O., \& Rosado, M. S. (2008). Controle da higienização na indústria de alimentos. In Andrade, N. J. (Ed.), Controle higienização na indústria de alimentos (cap. 4, pp. 185-229). São Paulo: Livraria Varela.

Angelo, K. M., Chu, A., Anand, M., Nguyen, T. A., Bottichio, L., Wise, M., Williams, I., Seelman, S., Bell, R., Fatica, M., Lance, S., Baldwin, D., Shannon, K., Lee, H., Trees, E., Strain, E., Gieraltowski, L., \& Centers for Disease Control and Prevention (CDC) (2015). Outbreak of Salmonella Newport infections linked to cucumbers - United States, 2014. MMWR. Morbidity and Mortality Weekly Report, 64(6), 144-147. PMid:25695319.

Bottichio, L., Medus, C., Sorenson, A., Donovan, D., Sharma, R., Dowell, N., Williams, I., Wellman, A., Jackson, A., Tolar, B., Griswold, T., \& Basler, C. (2016). Outbreak of salmonella oslo infections linked to persian cucumbers - United States, 2016. MMWR. Morbidity and Mortality Weekly Report, 65(50-51), 1430-1433. http://dx.doi. org/10.15585/mmwr.mm655051a3. PMid:28033312.

Brasil, Agência Nacional de Vigilância Sanitária. (1988, Agosto 23). Portaria $\mathrm{n}^{\circ} 15$, de 23 de agosto de 1988. Determina que o registro de produtos saneantes domissanitários com finalidade antimicrobiana seja procedido de acordo com as normas regulamentares. Diário Oficial da União, Poder Executivo. Retrieved from: http://www.cvs. saude.sp.gov.br/zip/u_pt-anvisa-015_230888.pdf

Brasil, Ministério da Saúde, Agência Nacional de Vigilância Sanitária. (2007). RDC no 14, de 28 de fevereiro de 2007. Aprova Regulamento Técnico para Produtos com Ação Antimicrobiana, harmonizado no âmbito do Mercosul, e dá outras providências. Diário Oficial da União. Retrieved from: http://portal.anvisa.gov.br/documents/10181/2718376/ RDC_14_2007.pdf/3eda65f3-5e07-40b5-b3fb-c85bfdcabec6

Centers for Disease Control and prevention - CDC. (2016). Multistate outbreak of Salmonella Saintpaul infections linked to imported cucumbers (Final Update). Retrieved from: https://www.cdc.gov/ salmonella/poona-09-15/

Downes, F. P., \& Ito, K. (2001). Compendium of methods for the microbiological examination of foods. Washington: American Public Health Association. http://dx.doi.org/10.2105/9780875531755.

Fantuzzi, E., Puschmann, R., \& Vanetti, M. C. D. (2004). Microbiota contaminante em repolho minimamente processado. Food Science and Technology, 24(2), 207-211. http://dx.doi.org/10.1590/S010120612004000200008.

Fernandes, G. R. (2013). Sanitizantes alternativos na qualidade microbiológica, física e química de morangos (Fragaria X Ananassa Duch) minimamente processados (Doctoral thesis). Universidade Federal de Viçosa, Viçosa.

Fernandes, P. É., São José, J. F. B., Zerdas, E. R. M. A., Andrade, N. J., Fernandes, C. M., \& Silva, L. D. (2014). Influence of the hydrophobicity and surface roughness of mangoes and tomatoes on the adhesion of Salmonella enterica serovar Typhimurium and evaluation of cleaning procedures using surfactin. Food Control, 41, 21-26. http://dx.doi. org/10.1016/j.foodcont.2013.12.024.

Food Safety Brazil. (2016). Surtos por Salmonella: dados estatísticos, sintomas e prevenção. Retrieved from: http://foodsafetybrazil.org/ surtos-por-salmonella-dados-estatisticos-sintomas-e-prevencoes

Food Safety Brazil. (2019). Surtos alimentares no Brasil - Dados atualizados em junho de 2018. Retrieved from: https://foodsafetybrazil.org/ surtos-alimentares-no-brasil-dados-atualizados-junho-de-2018-2/

Gomes, T. A., Salvador Filho, M. R. S., Zielinski, A. A. F., Pietrowski, G. A. M., \& Nogueira, A. (2014). Microbial levels in apple must and their association with fruit selection, washing and sanitization. Journal of Food Safety, 34(2), 141-149. http://dx.doi.org/10.1111/jfs.12107.

Guo, Y., Li, M., Han, H., \& Cai, J. (2016). Salmonella enterica serovar Choleraesuis on fresh-cut cucumber slices after reduction treatments. Food Control, 70, 20-25. http://dx.doi.org/10.1016/j. foodcont.2016.05.030.

Gurtler, J. B., Bailey, R. B., Jin, T. Z., \& Fan, X. (2014). Reduction of an E. coli O157:H7 and Salmonella composite on fresh strawberries by varying antimicrobial washes and vacuum perfusion. International Journal of Food Microbiology, 189, 113-118. http://dx.doi.org/10.1016/j. ijfoodmicro.2014.08.005. PMid:25146462.

Huang, Y., \& Chen, H. (2011). Effect of organic acids, hydrogen peroxide and mild heat on inactivation of Escherichia coli O157:H7 on baby spinach. Food Control, 22(8), 1178-1183. http://dx.doi.org/10.1016/j. foodcont.2011.01.012.

Huang, Y., Ye, M., \& Chen, H. (2012). Efficacy of washing with hydrogen peroxide followed by aerosolized antimicrobials as a novel sanitizing process to inactivate Escherichia coli O157:H7 on baby spinach. International Journal of Food Microbiology, 153(3), 306-313. http:// dx.doi.org/10.1016/j.ijfoodmicro.2011.11.018. PMid:22177228.

In, Y.-W., Kim, J.-J., Kim, H.-J., \& Oh, S.-W. (2013). Antimicrobial activities of acetic acid, citric acid and lactic acid against Shigella species. Journal of Food Safety, 33(1), 79-85. http://dx.doi.org/10.1111/ jfs. 12025.

Joshi, K., Mahendran, R., Alagusundaram, K., Norton, T., \& Tiwari, B. K. (2013). Novel disinfectants for fresh produce. Trends in Food Science \& Technology, 34(1), 54-61. http://dx.doi.org/10.1016/j. tifs.2013.08.008.

Lima, P. M., São José, J. F. B., Andrade, N. J., Pires, A. C. S., \& Ferreira, S. O. (2013). Interaction between natural microbiota and physicochemical characteristics of lettuce surfaces can influence the attachment of Salmonella Enteritidis. Food Control, 30(1), 157-161. http://dx.doi. org/10.1016/j.foodcont.2012.06.039. 
Linley, E., Denyer, S. P., McDonnell, G., Simons, C., \& Maillard, J.-Y. (2012). Use of hydrogen peroxide as a biocide: new consideration of its mechanisms of biocidal action. The Journal of Antimicrobial Chemotherapy, 67(7), 1589-1596. http://dx.doi.org/10.1093/jac/ dks129. PMid:22532463.

Mani-López, E., García, H. S., \& López-Malo, A. (2012). Organic acids as antimicrobials to control Salmonella in meat and poultry products. Food Research International, 45(2), 713-721. http://dx.doi. org/10.1016/j.foodres.2011.04.043.

Mukhopadhyay, S., Sokorai, K., Ukuku, D. O., Fan, X., Olanya, M., \& Juneja, V. (2019). Effects of pulsed light and sanitizer wash combination on inactivation of Escherichia coli O157:H7, microbial loads and apparent quality of spinach leaves. Food Microbiology, 82, 127-134. http://dx.doi.org/10.1016/j.fm.2019.01.022. PMid:31027766.

Nascimento, M. S., \& Silva, N. (2010). Tratamentos químicos na sanitização de morango (Fragaria vesca L). Brazilian Journal of Food Technology, 13(1), 11-17. http://dx.doi.org/10.4260/BJFT2010130100002.

Neal, J. A., Marquez-Gonzalez, M., Cabrera-Diaz, E., Lucia, L. M., O’Bryan, C. A., Crandall, P. G., Ricke, S. C., \& Castillo, A. (2012). Comparison of multiple chemical sanitizers for reducing Salmonella and Escherichia coli O157:H7 on spinach (Spinacia oleracea) leaves. Food Research International, 45(2), 1123-1128. http://dx.doi. org/10.1016/j.foodres.2011.04.011.

Ölmez, H., \& Kretzschmar, U. (2009). Potential alternative disinfection methods for organic fresh-cut industry for minimizing water consumption and environmental impact. Lebensmittel-Wissenschaft + Technologie, 42(3), 686-693. http://dx.doi.org/10.1016/j.lwt.2008.08.001.

Palharini, M. C. A., Santos, C. A. J. P., Fileti, M. S., Simionato, E. M. R. S., \& Sasaki, F. F. C. F. (2017). Peróxido de hidrogênio no controle de patógenos e do escurecimento enzimático de vagem minimamente processada. Comunicata Scientiae, 8(1), 69-79. http:// dx.doi.org/10.14295/cs.v8i1.1429.

Park, S. H., Choi, M. R., Park, J. W., Park, K. H., Chung, M. S., Ryu, S., \& Kang, D. H. (2011). Use of organic acids to inactivate Escherichia coli O157:H7, Salmonella Typhimurium, and Listeria monocytogenes on organic fresh apples and lettuce. Journal of Food Science, 76(6), M293-M298. http://dx.doi.org/10.1111/j.1750-3841.2011.02205.x. PMid:21623781.

Paula, N. R. F., Vilas Boas, E. V. B., Rodrigues, L. J., Carvalho, R. A., \& Piccoli, R. H. (2009). Qualidade de produtos minimamente processados e comercializados em gôndolas de supermercados nas cidades de Lavras - MG, Brasília - DF e São Paulo - SP. Ciência e Agrotecnologia, 33(1), 219-227. http://dx.doi.org/10.1590/S141370542009000100031.

Poimenidou, S. V., Bikouli, V. C., Gardeli, C., Mitsi, C., Tarantilis, P. A., Nychas, G.-J., \& Skandamis, P. N. (2016). Effect of single or combined chemical and natural antimicrobial interventions on Escherichia coli $\mathrm{O} 157: \mathrm{H7}$, total microbiota and color of packaged spinach and lettuce. International Journal of Food Microbiology, 220, 6-18. http:// dx.doi.org/10.1016/j.ijfoodmicro.2015.12.013. PMid:26773252.

Ramos, B., Miller, F. A., Brandão, T. R. S., Teixeira, P., \& Silva, C. L. M. (2013). Fresh fruits and vegetables - An overview on applied methodologies to improve its quality and safety. Innovative Food Science \& Emerging Technologies, 20, 1-15. http://dx.doi.org/10.1016/j. ifset.2013.07.002.

Rico, D., Martín-Diana, A. B., Barat, J. M., \& Barry-Ryan, C. (2007). Extending and measuring the quality of fresh-cut fruit and vegetables: a review. Trends in Food Science \& Technology, 18(7), 373-386. http:// dx.doi.org/10.1016/j.tifs.2007.03.011.

Rosário, D. K. A., Mutz, Y. S., Peixoto, J. M. C., Oliveira, S. B. S., Carvalho, R. V., Carneiro, J. C. S., São José, J. F. B., \& Bernardes, P. C. (2017). Ultrasound improves chemical reduction of natural contaminant microbiota and Salmonella enterica subsp. Enterica on strawberries.
International Journal of Food Microbiology, 241, 23-29. http://dx.doi. org/10.1016/j.ijfoodmicro.2016.10.009. PMid:27743521.

Sagong, H.-G., Lee, S.-Y., Chang, P.-S., Heu, S., Ryu, S., Choi, Y.-J., \& Kang, D.-H. (2011). Combined effect of ultrasound and organic acids to reduce Escherichia coli O157:H7, Salmonella Typhimurium, and Listeria monocytogenes on organic fresh lettuce. International Journal of Food Microbiology, 145(1), 287-292. http://dx.doi.org/10.1016/j. ijfoodmicro.2011.01.010. PMid:21276633.

São José, J. F. B. (2013). Caracterização físico-química e microbiológica de tomate cereja (Lycopersicum esculentum var. cerasiforme) minimamente processado submetido a diferentes tratamentos de sanitização (Doctoral thesis). Universidade Federal de Viçosa, Viçosa.

São José, J. F. B., \& Vanetti, M. C. D. (2012). Effect of ultrasound and commercial sanitizers in removing natural contaminants and Salmonella enterica Typhimurium on cherry tomatoes. Food Control, 24(1-2), 95-99. http://dx.doi.org/10.1016/j.foodcont.2011.09.008.

São José, J. F. B., \& Vanetti, M. C. D. (2015). Application of ultrasound and chemical sanitizers to watercress, parsley and strawberry: Microbiological and physicochemical quality. LebensmittelWissenschaft + Technologie, 63(2), 946-952. http://dx.doi.org/10.1016/j. lwt.2015.04.029.

São José, J. F. B., Medeiros, H. S., Andrade, N. J., Ramos, A. M., \& Vanetti, M. C. D. (2018). Effect of ultrasound and chemical compounds on microbial contamination, physicochemical parameters and bioactive compounds of cherry tomatoes. Italian Journal of Food Science, 30(3). http://dx.doi.org/0.1016/j.fm.2012.04.016.

São José, J. F. B., Medeiros, H. S., Bernardes, P. C., \& Andrade, N. J. (2014). Removal of Salmonella enterica Enteritidis and Escherichia coli from green peppers and melons by ultrasound and organic acids. International Journal of Food Microbiology, 190, 9-13. http://dx.doi. org/10.1016/j.ijfoodmicro.2014.08.015. PMid:25173914.

Smanioto, T. F., Pirolo, N. J., Simionato, E. M. R. S., \& Arruda, M. C. (2009). Qualidade microbiológica de frutas e hortaliças minimamente processadas. Revista do Instituto Adolfo Lutz, 68(1), 150-154.

Ukuku, D. O. (2004). Effect of hydrogen peroxide treatment on microbial quality and appearance of whole and fresh-cut melons contaminated with Salmonella spp. International Journal of Food Microbiology, 95(2), 137-146. http://dx.doi.org/10.1016/j.ijfoodmicro.2004.01.021. PMid:15282126.

Ukuku, D. O. (2006). Effect of sanitizing treatments on removal of bacteria from cantaloupe surface, and re-contamination with Salmonella. Food Microbiology, 23(3), 289-293. http://dx.doi.org/10.1016/j. fm.2005.04.002. PMid:16943016.

Valiolahi, M., Najafi, M. A., Eskandani, M. A., \& Rahnama, M. (2019). Effects of organic acid alone and in combination with $\mathrm{H}_{2} \mathrm{O} 2$ and $\mathrm{NaCl}$ on Escherichia coli O157:H7: an evaluation of antioxidant retention and overall acceptability in Basil leaves (Ocimum basilicum). International Journal of Food Microbiology, 292, 56-63. http://dx.doi. org/10.1016/j.ijfoodmicro.2018.12.010. PMid:30576940.

Wang, C., Chang, T., Yang, H., \& Cui, M. (2015). Antibacterial mechanism of lactic acid on physiological and morphological properties of Salmonella Enteritidis, Escherichia coli and Listeria monocytogenes. Food Control, 47, 231-236. http://dx.doi.org/10.1016/j. foodcont.2014.06.034.

Wieczyńska, J., Luca, A., Kidmose, U., Cavoski, I., \& Edelenbos, M. (2016). The use of antimicrobial sachets in the packaging of organic wild rocket: Impact on microorganisms and sensory quality. Postharvest Biology and Technology, 121, 126-134. http://dx.doi.org/10.1016/j. postharvbio.2016.07.011.

Yuk, H.-G., Bartz, J. A., \& Schneider, K. R. (2006). The Effectiveness of Sanitizer Treatments in Inactivation of Salmonella spp. from Bell 
Pepper, Cucumber, and Strawberry. Journal of Food Science, 71(3), M95-M99. http://dx.doi.org/10.1111/j.1365-2621.2006.tb15638.x.

Zhang, J., \& Yang, H. (2017). Effects of potential organic compatible sanitisers on organic and conventional fresh-cut lettuce (Lactuca sativa Var. Crispa L). Food Control, 72, 20-26. http://dx.doi.org/10.1016/j. foodcont.2016.07.030.
Zhang, M., Oh, J. K., Huang, S.-Y., Lin, Y.-R., Liu, Y., Mannan, M. S., Cisneros-Zevallos, L., \& Akbulut, M. (2015). Priming with nanoaerosolized water and sequential dip-washing with hydrogen peroxide: An efficient sanitization method to inactivate Salmonella Typhimurium LT2 on spinach. Journal of Food Engineering, 161, 8-15. http://dx.doi.org/10.1016/j.jfoodeng.2015.03.026. 